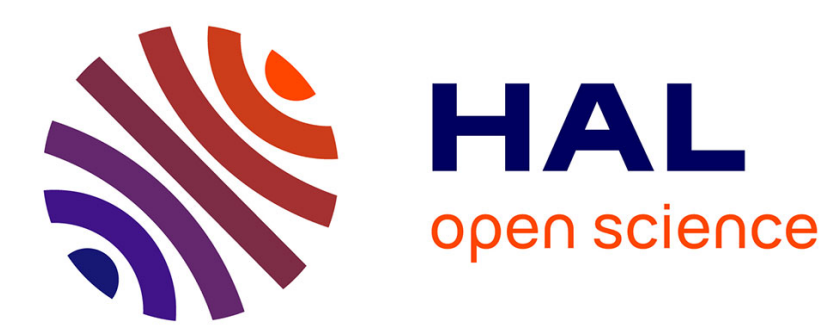

\title{
Earthquake fault rock indicating a coupled lubrication mechanism
}

\author{
S. Okamoto, G. Kimura, S. Takizawa, H. Yamaguchi
}

\section{To cite this version:}

S. Okamoto, G. Kimura, S. Takizawa, H. Yamaguchi. Earthquake fault rock indicating a coupled lubrication mechanism. eEarth, 2006, 1 (1), pp.23-28. hal-00298228

\section{HAL Id: hal-00298228}

\section{https://hal.science/hal-00298228}

Submitted on 20 Dec 2006

HAL is a multi-disciplinary open access archive for the deposit and dissemination of scientific research documents, whether they are published or not. The documents may come from teaching and research institutions in France or abroad, or from public or private research centers.
L'archive ouverte pluridisciplinaire HAL, est destinée au dépôt et à la diffusion de documents scientifiques de niveau recherche, publiés ou non, émanant des établissements d'enseignement et de recherche français ou étrangers, des laboratoires publics ou privés. 


\title{
Earthquake fault rock indicating a coupled lubrication mechanism
}

\author{
S. Okamoto ${ }^{1}$, G. Kimura ${ }^{1,2}$, S. Takizawa ${ }^{3}$, and H. Yamaguchi ${ }^{2}$ \\ ${ }^{1}$ Department of Earth and Planetary Science, the University of Tokyo, Hongo 7-3-1, Bunkyo-Ku, Tokyo, 113-0033, Japan \\ ${ }^{2}$ The Institute for Frontier Research on Earth Evolution, Japan Agency for Marine-Earth Science and Technology, Natsushima \\ 2-15, Natsushima-cho, Yokosuka-city, Kanagawa, 237-0061, Japan \\ ${ }^{3}$ Institute of Geoscience, University of Tsukuba, 1-1-1 Tennodai, Tsukuba, Ibaraki, 305-8577, Japan
}

Received: 28 June 2006 - Published in eEarth Discuss.: 7 August 2006

Revised: 8 November 2006 - Accepted: 1 December 2006 - Published: 20 December 2006

\begin{abstract}
A pseudotachylyte bounded by a carbonate-matrix implosion breccia was found at a fossilized out-of-sequence thrust in the Shimanto accretionary complex, Japan. This occurrence resulted from the following events: first implosion of host rock due to interstitial fluid pressure increase and asymmetric fracturing; second, $\mathrm{Ca}-\mathrm{Fe}-\mathrm{Mg}$ carbonate precipitation; and third, frictional melting. The rock-record suggests that these events took place in a single seismogenic slip event. Resulting from abrupt drop in fluid pressure after implosion, hydro-fracturing and fluid escape, recovered high effective friction promoted melting during fault movement. Coexistence of fluid implosion breccia and pseudotachylyte has never been reported from continental pseudotachylytes, but might be characteristic from hydrous seismogenic faults in subduction zones.
\end{abstract}

\section{Introduction}

Pseudotachylyte formed by frictional melting has been the only convincing geologic evidence of rapid slip along seismogenic faults (e.g. Spray, 1992, Cowan, 1999). Under hydrous conditions, however, frictional melting has been considered to be prevented and other mechanisms, such as thermal pressurization of pore fluid (Sibson, 1973, 1975; Lachenbruch, 1980; Mase and Smith, 1987), acoustic fluidization (Melosh, 1996: Otsuki et al., 2003), or elastohydrodynamic lubrication (Brodsky and Kanamori, 2001), were thought to contribute to the dynamic weakening for unstable slip of earthquakes. In the seismogenic subduction zone, therefore, the predominant mechanisms have been implicitly considered to be fluid-induced weakening without frictional

\section{Correspondence to:}

S. Okamoto (shinya@eps.s.u-tokyo.ac.jp)

G. Kimura (gaku@eps.s.u-tokyo.ac.jp) melting because the subduction zone is fundamentally rich in water under relatively low temperature conditions.

Recently geological evidence of frictional melting has been increasingly reported from several ancient accretionary prisms uplifted from seismogenic depths of subduction zones (Ikesawa et al., 2003; Austrheim and Andersen, 2004; Kitamura et al., 2005; Rowe et al., 2005; Mukoyoshi et al., 2006) but the relationship between the conflicting mechanisms; e.g. thermal pressurization of fluid and frictional melting is still unclear.

We found a new exposure of pseudotachylyte from a fossilized out-of-sequence thrust (OOST) in an exposed accretionary prism. This unique fault, not previously reported, is associated with an implosion breccia embedded in a precipitated carbonate matrix, suggesting that both thermal pressurization of fluid/hydrofracturing (Sibson, 1986) and frictional melting operated. In this paper, we first describe the fault rock and then discuss dynamic weakening process in the hydrous seismogenic fault.

\section{Geologic setting}

The Nobeoka thrust is an OOST bounding the northern and southern Shimanto Belts of the Cretaceous-Tertiary accretionary complex in Kyushu, southwest Japan (Fig. 1). The thrust is traceable for more than $300 \mathrm{~km}$ in the Shimanto Belt, parallel to the modern Nankai Trough.

Hanging-wall rocks of the thrust are composed of the Eocene Kitagawa Group of plastically deformed meta-shales and meta-sandstones. Foot-wall strata of the Eocene Hyuga Group are composed of shale matrix mélange with sandstone and basaltic blocks deformed mainly by a brittle mechanism. The deformation fabrics of these rocks are consistent with the sense of shear along the Nobeoka Thrust (Kondo et al., 2005). Geo-thermometry using vitrinite reflectance indicates that the Kitagawa and the Hyuga Groups experienced heating

Published by Copernicus GmbH on behalf of the European Geosciences Union. 


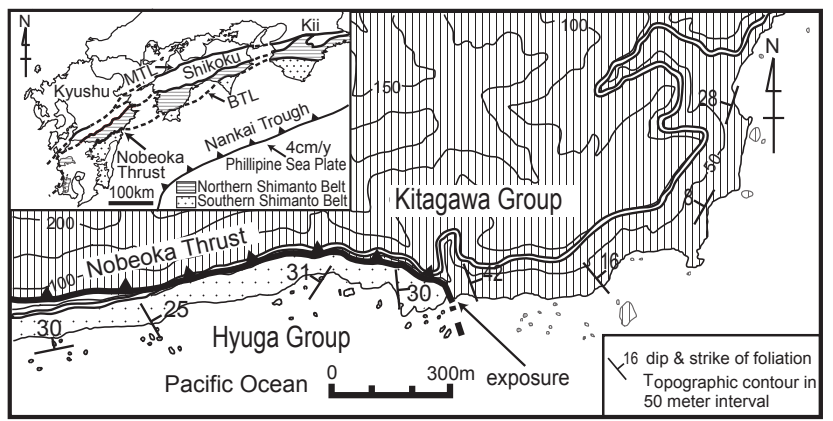

Fig. 1. Location map of the Nobeoka thrust and exposure of the studied fault. MTL is the Median Tectonic Line. BTL is the Butsuzo Tectonic Line.

up to maximum temperatures of about $320^{\circ}$ and about $250^{\circ}$, respectively (Kondo et al., 2005). The Nobeoka thrust is characterized by a cataclastic fault core about $20 \mathrm{~cm}$ thick and by a brittle damage zone whose thickness is several tens of meters in the hanging-wall and about $100 \mathrm{~m}$ in the foot-wall. Ubiquitous subsidiary shears, whose orientation is parallel to that of the fault core of the Nobeoka thrust, are present in the damaged zone.

Kondo et al. (2005) pointed out that the Nobeoka Thrust was formed at seismogenic depths from the viewpoint of thermal models (e.g. Hyndman et al., 1997), in comparison with the OOST in the modern Nankai Trough (Park et al., 2002) and on the basis of cataclastic deformation with fluid flow although direct evidence such as pseudotachylyte was not documented.

\section{Asymmetric crack, implosion breccia and pseudo- tachylyte}

This unique fault rock was found from one of the subsidiary faults in the hanging wall about $10 \mathrm{~m}$ above the fault core of the Nobeoka thrust. The subsidiary fault is composed of two different parts along the fault surface: narrow, planar slip sections and wider zones along dilation jogs (Fig. 2A). The planar slip section shows two-stages of deformation as documented by the cross-cutting relationship, first by asymmetric extensional cracking, especially in the foot-wall, then by frictional melting. The dilation jogs apparently deformed by a single stage of implosion.

3.1 Implosion breccia of the boundary of the fault core, dilation jog and asymmetric extensional cracks

The fault core of the slip sections is bounded mainly by host rocks but partly by a cataclasite-like zone (Fig. 2D). The zone is bounded by a clear wavy wall from the host in the hanging wall and connected with cracks in the foot-wall (Figs. 2A and 2B).
The cataclasite-like zone is composed of breccias of the host rock made of grains of various size embedded in a dark matrix. EPMA (Electron Probe Micro-Analyzer) and XRD (X-ray Diffractometer) analyses give evidence that the matrix is made of precipitated $\mathrm{Ca}-\mathrm{Fe}-\mathrm{Mg}$ carbonates that are not found in the host rocks.

The breccia is also present in cracks in the foot-wall and the dilation jogs (Figs. 2A-2D). The shapes of the cracks are irregular, but orientations $\sim 30-40^{\circ}$ clockwise from the slip plane dominate. Fewer cracks are orientated parallel to the foliation of the host rocks (Figs. 2A and 2F). Thicknesses of the crack veins decrease with distance from the fault core (Figs. 2A and 2B). The lengths of the jogs are several tens of $\mathrm{cm}$ parallel to the slip direction (Fig. 2A), which is minimum indication of displacement along the fault.

The dilation jogs are filled by $\mathrm{Ca}-\mathrm{Fe}-\mathrm{Mg}$ carbonates that encircle breccias of host rocks (Figs. 2A and 2D). The component is similar to that of the implosion breccia observed in the slip part as described. Crystal sizes of carbonates are smaller than a few tens of $\mu \mathrm{m}$ (Fig. 3B).

\subsection{Pseudotachylyte}

$1 \mathrm{~mm}$ thick fault core along the slip part of the fault is composed mainly of materials that are translucent under the optical microscope (Fig. 2E). Chemical analysis by EPMA (Fig. 4A), crystallographic analysis by XRD (Fig. 4B) and TEM (Transmission Electron Micrograph) analysis (Fig. $3 \mathrm{H}$ ) revealed that the pseudotachylyte is now composed dominantly of palygroskite $\left(\mathrm{Al}_{2} \mathrm{Fe} \square_{2} \mathrm{Si}_{8} \mathrm{O}_{20}(\mathrm{OH})_{2}\left(\mathrm{OH}_{2}\right)_{4} \mathrm{Mg}\left(\mathrm{H}_{2} \mathrm{O}\right)_{4}\right)$ and amorphous materials. The sign $(\square)$ in the chemical formula means vacancy in the crystal structure. Survival fragments are quartz, calcite and illite-chlorite aggregates. Palygorskite is never found in the host rocks (Fig. 4B).

SEM-BSI (Scanning Electron Microscope- Back Scatter Image) enabled the observation of various melt-and-quench related features of pseudotachylyte. The pseudotachylyte constitutes the "upper and lower domains" in Fig. 3A. The "upper domain" is composed of homogeneous matrix containing a few fragments of quartz, calcite and illite-chlorite aggregates. Margins of the fragments are plastically deformed and show embayment and frame texture due to the melting (Figs. 3D and 3E). Fe-rich micro-spherules with diameter of several $\mu \mathrm{m}$ are distributed along the hanging-wall of the upper domain (Figs. $3 \mathrm{C}$ and $3 \mathrm{H}$ ). The size of the spherules becomes larger toward the upper margin (Fig. 3C). Their crystallization might have resulted from oxidation of $\mathrm{Fe}$ in melt during the melt-quenching event (Nakamura et al., 2002).

Elongated voids whose size is a few to several $\mu \mathrm{m}$ are recognized in the upper domain (Figs. 3A and 3E). Elongated voids show internal tiny vesicles and globular material surfaces (Fig. 3G) similar to features described by Kennedy and Spray (1992). Stretched icicle-like features are observed 


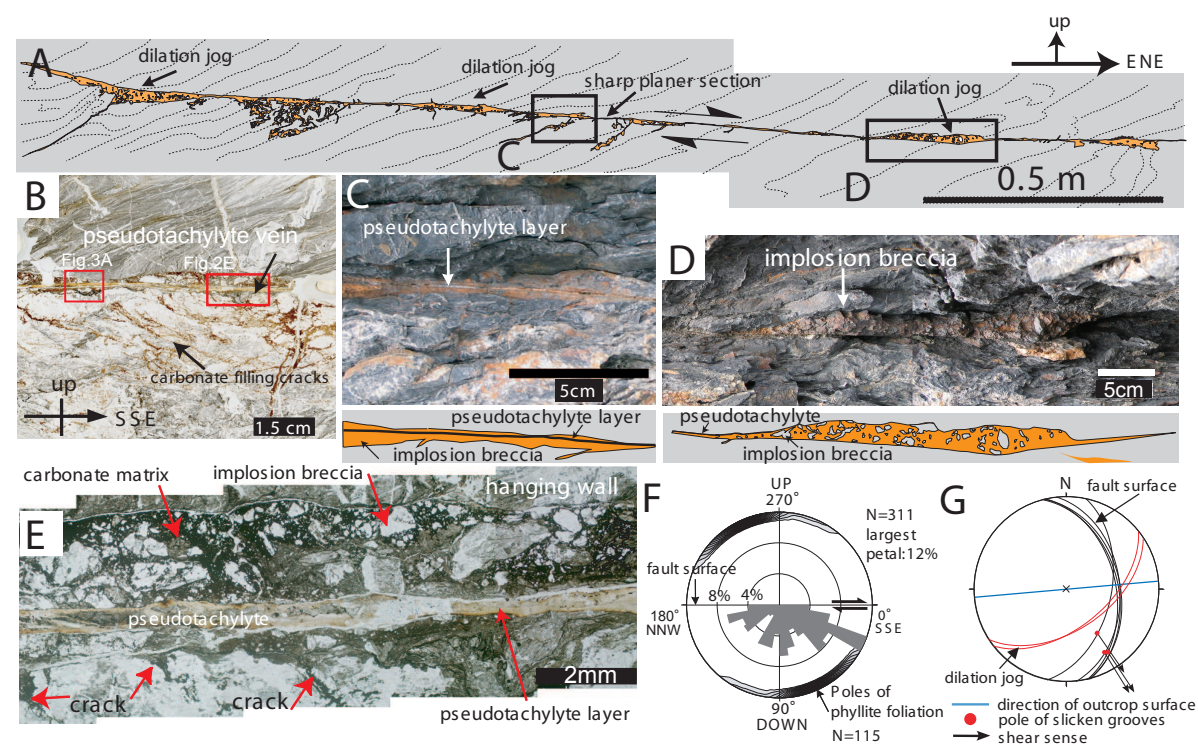

Fig. 2. Sketch and photographs of the studied fault. (A) sketch of the fault. Outcrops are oblique to the slip direction (SSE). Note that the fault is composed of two parts: sharp planar sections and dilation jogs. (B) and (C) Outcrop of slipped part. (D) Outcrop of dilation jog. (E) Photomicrograph of the slipped part. Note that translucent fault core is bounded by cataclasite-like breccia in the dark carbonate matrix. (F) Orientation frequency diagram of cracks filled by carbonate together with lower-hemisphere stereograph of foliations. The orientation is measured on thin sections in parallel to the slip direction and perpendicular to the fault plane, foliations of host-rock phyllite and the cracks. Note that predominant orientations are $30^{\circ} \sim 40^{\circ}$ clockwise from the slipped plane. Other large cracks are controlled by foliation as shown in (A). (G) Stereographic projection (lower hemisphere) of the orientation of the step walls of the dilation jog, fault plane and slip. Note that the orientation of the step wall is perpendicular to the slip direction.

within the cracks (Fig. 3F). Cooling cracks enveloping partially molten grains are also well displayed (Fig. 3D).

The lower domain consists dominantly of ultracataclastic aggregates (Fig. 3A). Margins of fragments mostly retain their original shapes although partially molten, especially in the illite/chlorite aggregates. Larger fragments are concentrated in the upper part of the lower domain and floated in the upper molten domain (Fig. 3A). Such aspects resemble grain flow textures of sediments.

The pseudotachylyte, especially the completely molten upper domain, pinches out as the dilation jog filled by implosion breccia is approached (Fig. 2D).

\section{Discussion}

Here we discuss the characteristic aspects of the fault described above and its significance for the mechanics of seismogenic faults.

\subsection{A single slip fault}

The two staged deformation in the slip part show that fracturing with fluid implosion occurred first, followed by frictional melting. One can explain that there was a long hiatus between the two events and accidental slip along the same fracture. If this was the case, slip repetition should be recorded in the fault core (e.g. layered pseudotachylyte, Otsuki et al., 2003) and part of the dilation jog should be cut by the fault. The internal texture of pseudotachylyte, however, does not represent such a repetition, but rather represents a simple separation of upper and lower domains as described. The separation appears to be a gravitational effect because inverse grading texture of fragments resembles grain flow textures which are commonly observed in sediments. Thus, the fluid implosion with fracturing might have occurred early, with the frictional melting occurring later during a single slip event. The planar part fades into the dilation jog that is filled only by implosion breccia. This occurrence suggests that the fracturing was concentrated at the jog during slip propagation. Thus, the observed fault suggests a single slip event with several tens of $\mathrm{cm}$ displacement.

\subsection{Asymmetric cracking with implosion breccia}

Theoretically predicted cracking in the "process and damage" zones (Cowie and Scholz, 1992; Scholz et al., 1993) is observed in many natural examples (e.g. Vermilye and Scholz, 1998; Kim et al., 2004). They show that extensional Mode I fractures develop in parallel to the transient $\sigma 1$ in the vicinity of the fault tip, and/or around jogs, which progress to the damaged zone as a result of slip propagation (e.g. Kim et al., 2004). Asymmetric development, the angle between crack and fault surface, and the change in crack-width that 

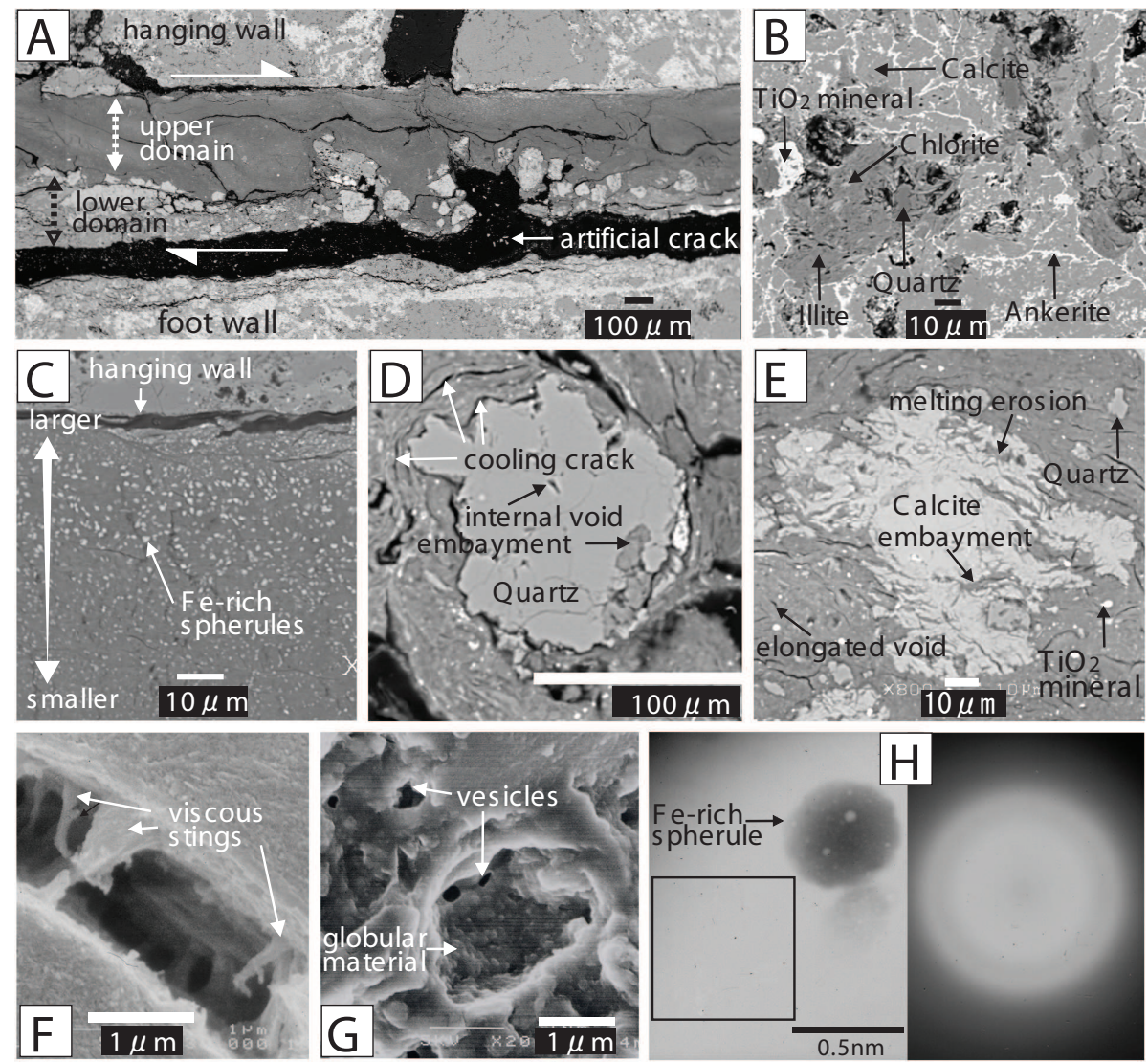

Fig. 3. SEM and TEM images for the pseudotachylyte. (A) Upper molten domain and lower ultracataclaste-dominated domain in the fault vein. (B) Implosion breccia encircled by carbonate matrix. Note that Carbonates are composed of a few $\mu \mathrm{m}$ calcite and grain boundary filling ankerite. (C) Concentration of Fe-rich spherules along the margin. Note that size of spherule enlarges along the margin. (D) Embayment and cooling cracks surrounding quartz grain in the upper domain. (E) Embayment and cooling cracks surrounding calcite. Note embayment of calcite more marked than that of quartz. (F) Icicle-like viscous stings in the cooling crack. (G) Globular surface and vesicles associated in the elongated void. (H) Left: TEM bright-field image of the pseudotachylyte. Right: Electron diffraction pattern in the box of the left documenting amorphous material.

we observed are quite consistent with those of the Mode I fractures in the damage zone (Kim et al., 2004).

A difference from commonly observed Mode I fractures is that the cracks are filled with carbonate and connected with the dilatant jog. Such an occurrence suggests that the Mode I rupture is not only due to transient stress concentration around the fault propagating tip or jog but also due to hydro-fracturing, that would have taken place due to a large fluid pressure gradient between the pore fluid in preceding cracks in the process zone or jog, and the damage zone (Billi et al., 2003). Such a large pressure difference between the source and sink collapses the wall and produces the implosion breccia (Sibson, 1986).

4.3 Ca-Fe-Mg carbonate precipitation for the matrix of implosion breccia

Crack-filling veins and matrices of implosion breccia are characteristically composed of $\mathrm{Ca}-\mathrm{Fe}-\mathrm{Mg}$ carbonates as de- scribed. The matrix-supported texture suggests rapid precipitation of carbonates because, if precipitation did not occur quickly, the grain structure would have collapsed, leading to a grain-supported structure. The mean diameter of matrix carbonate crystals is less than a few tens of $\mu \mathrm{m}$. Such tiny crystal aggregates are different from ordinary vein-filling carbonates and suggestive of abrupt precipitation, although the exact precipitation rate is unknown.

Carbonate solubility is controlled by $\mathrm{pH}, \mathrm{KH}$ and $\mathrm{CO}_{2}$ concentration of the fluid, which depend on pressuretemperature conditions (Holland, 1967; Holland and Malinin, 1979). Dynamic formation of extensional cracks and jogs results in adiabatic fluid expansion and sudden fluid pressure drop, which abruptly reduces the solubility of carbonates and lead to precipitation of the tiny crystals. 


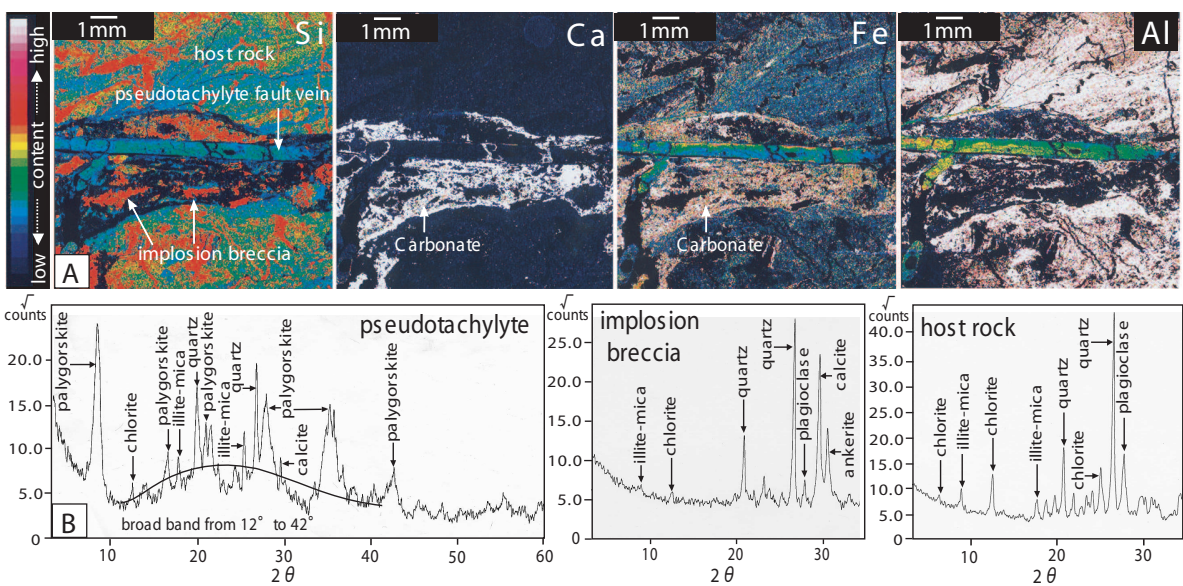

Fig. 4. (A) EPMA elements mapping of the pseudotachylyte, implosion breccia, and host rock. Note that $\mathrm{Si}, \mathrm{Fe}, \mathrm{Mg}$ and $\mathrm{Al}$ characterize the pseudotachylyte. Fe, $\mathrm{Mg}$ and $\mathrm{Ca}$ are found from the matrix of implosion breccia. Location for these maps is shown in Fig. 2E. (B) XRD analyses for the pseudotachylyte, implosion breccia, and host rock. Note the broad band ranging from $12^{\circ}$ to $42^{\circ}$ of the pseudotachylyte, which coincides with that of glassy material reported by (Lin and Shimamoto, 1998). Palygorskite and the broad band never presents in parts of implosion breccia and host rock, and calcite and ankerite are not found in the host rocks.

4.4 Fluid thermal pressurization to abrupt depressurization, and friction recovery to fusion melting

Friction in the beginning stage of slip easily raises the temperature along the slip plane. In this state, the interstitial fluid of the fault zone surrounded by impermeable host rock is thermally pressurized and attains lithostatic fluid pressure (Sibson, 1973; Lachenbruch, 1980; Mase and Smith, 1987; Melosh, 1996; Rice, 2005). Only a few $\mathrm{mm}$ to $\mathrm{cm}$ slip is enough to supply the energy for the thermal pressurization (Sibson, 1973; Lanchenbruch, 1980; Mase and Smith, 1987; Rice, 2005). If the lithostatic pressure is maintained, there is no effective shear strength on the slip plane which is lubricated. However, if the thermally raising fluid pressure exceeds the effective tensile strength, the pressure triggers the hydro-fracturing and implosion (e.g. Sibson, 1973; 1975). Such abrupt extensional fracturing suddenly drops the fluid pressure. The rapid decrease of the fluid pressure means that effective shear strength is recovered and shear heating goes again to fusion melting at the slip plane. Recovered friction might raise again the temperature and pressure of interstitial fluid in the damage zone and might enhance the fluid flow into the dilatant jog. Rock records observed in this study suggests such a dynamic feedback may have occured in the stage of slip propagation of seismogenic faulting in a subduction zone, although quantitative temperature and pressure estimation due to thermal pressurization and its associated time-scale are still to be determined in the future.

Acknowledgements. This study was supported by the Plate Dynamic Program of Japan Agency for Marine-Earth Science \& Technology, and the 21st Century Center of Excellence Program of the University of Tokyo. Our fieldwork was supported by T. Kanda, University of Miyazaki. We are grateful to Y. Kaneda,
A. Yamaguchi, K. Ujiie, A. Sakaguchi, Y. Kitamura, H. Raimbourg, and K. Ozawa for fruitful discussions. We also thank G. Moore and C. J. Moore for reviewing the paper and improving an early version.

Edited by: C. R. Ranero

\section{References}

Austrheim, H. K. and Andersen, T. B.: Pseudotachylytes from Corsica: fossil earthquakes from a subduction complex, Terra Nova., 16, 193-197, 2004.

Billi, A., Salvini, F., and Storti, F.: The damage zone-fault core transition in carbonate rocks: implications for fault growth, structure and permeability, J. Struct. Geol., 25, 1779-1794, 2003.

Brodsky, E. E. and Kanamori, H.: Elastohydrodynamic lubrication of faults, J. Geophys. Res., 106, 16357-16374, 2001.

Cowan, D. S.: Do faults preserve a record of seismic slip? A field geologist's opinion, J. Struct. Geol., 21, 995-1001, 1999.

Cowie, P. A. and Scholz, C. H.: Physical explanation for the displacement length relationship of faults using a post-yield fracture-mechanics model, J. Struct. Geol., 14, 1133-1148, 1992.

Holland, H. D.: Gangue minerals in hydrothermal deposits, Geochemistry of Hydrothermal Ore Deposits, edited by: Barnes, H. L., Wiley-Interscience New York, 382-436, 1967.

Holland, H. D. and Malinin, S. D.: The solubility and occurrence of non-ore minerals, Geochemistry of Hydrothermal Ore Deposits, 2nd ed., edited by: Barnes, H. L., Wiley-Interscience New York, 461-508, 1979.

Hyndman, R. D., Yamano, M., and Oleskevich, D. A.: The seismogenic zone of subduction thrust faults, Island Arc, 6, 244-260, 1997.

Ikesawa, E., Sakaguchi, A., and Kimura, G.: Pseudotachylyte from an ancient accretionary complex: Evidence for melt generation 
during seismic slip along a master decollement?, Geology, 31, 637-640, 2003.

Kennedy, L. A. and Spray, J. G.: Frictional melting of sedimentaryrock during high-speed diamond drilling - An analytical SEM and TEM investigation, Tectonophysics, 204, 323-337, 1992.

Kim, Y. S., Peacock, D. C. P., and Sanderson, D. J.: Fault damage zones: Journal of Structural Geology, J. Struct. Geol., 26, 503$517,2004$.

Kitamura, Y., Sato, K., Ikesawa, E., Ikehara-Ohmori, K., Kimura, G., Kondo, H., Ujiie, K., Onishi, C.T., Kawabata, K., Hashimoto, Y., Mukoyoshi, H., and Masago, H.: Mélange and its seismogenic roof décollement : A plate boundary fault rock in the subduction zone - an example from the Shimanto belt, Japan, Tectonics, 24, TC5012, doi:10.1029/2004TC001635, 2005.

Kondo, H., Kimura G., Hideki M., Ohmori-Ikehara, K., Kitamura, Y., Ikesawa, E., Sakaguchi, A., Yamaguchi, A., and Okamoto, S.: Melange and its seismogenic roof decollement: A plate boundary fault rock in the subduction zone - An example from the Shimanto Belt, Japan-, Tectonics, 24, TC6008, doi:10.1029/20042004TC001655, 2005.

Lachenbruch, A. H.: Frictional heating, fluid pressure, and the resistance to fault motion, J. Geophys. Res., 85, 6097-6112, 1980.

Lin, A. M. and Shimamoto, T.: Selective melting processes as inferred from experimentally generated pseudotachylytes, J. Asian Earth Sci., 16, 533-545, 1998.

Mase, C. W. and Smith, L.: Effects of frictional heating on the thermal, hydrologic, and mechanical response of a fault, J. Geophys. Res., 92, 6249-6272, 1987.

Melosh, H. J.: Dynamical weakening of faults by acoustic fluidization, Nature, 379, 601-606, 1996.

Mukoyoshi, H., Sakaguchi, A., Otsuki, K., Hirono, T., and Soh, W.: Co-seismic frictional melting along an out-of-sequence thrust in the Shimanto accretionary complex. Implication on the tsunamigenic potential of splay faults in modern subduction zones, Earth Planet. Sci. Lett., 245, 330-343, 2006.
Nakamura, N., Hirose, T., and Borradaile, G. J.: Laboratory verification of submicron magnetite production in pseudotachylytes, Earth Planet. Sci. Lett., 201, 13-18, 2002.

Otsuki, K., Monzawa, N., and Nagase, T.: Fluidization and melting of fault gouge during seismic slip: Identification in the Nojima fault zone and implications for focal earthquake mechanisms, J. Geophys. Res., 108, doi:10.1029/2001JB001711, 2003.

Park, J. O., Tsuru, T., Kodaira, S., Cummins, P. R., and Kaneda, Y.: Splay fault branching along the Nankai subduction zone, Science, 297, 1157-1160, 2002.

Rice, J. R.: Mechanical role of fluid in earthquakes and faulting, AGU Fall Meeting, T43C-03, 389, 2005.

Rowe, C. D., Moore, J. C., Meneghini, F., and McKeirnan, A. W.: Large-scale pseudotachylytes and fluidized cataclasites from an ancient subduction thrust fault, Geology, 33, 937-940, 2005.

Scholz, C. H., Dawers, N. H., Yu, J. Z., and Anders, M. H.: Fault growth and fault scaling laws - Preliminary-results, J. Geophys. Res., 98, 21 951-21 961, 1993.

Sibson, R. H.: Interactions between temperature and pore-fluid pressure during earthquake faulting and a mechanism for partial or total stress relief: Nature-Physical Science, Nature, 243, 66-68, 1973.

Sibson, R. H.: Generation of pseudotachylyte by ancient seismic faulting, Geophys. J. R. Astron. Soc., 43, 775-794, 1975.

Sibson, R. H.: Brecciation processes in fault zones - Inferences from earthquake rupturing, Pure Appl. Geophys., 124, 159-175, 1986.

Spray, J. G.: A physical basis for the frictional melting of some rock-forming minerals, Tectonophysics, 205, 19-34, 1992.

Vermilye, J. M. and Scholz, C. H.: The process zone: A microstructural view of fault growth, J. Geophys. Res., 103, 12 223-12 237, 1998.

Wibberley, C. A. J. and Shimamoto, T.: Earthquake slip weakening and asperities explained by thermal pressurization, Nature, 436, 689-692, 2005. 